\title{
Management of Impression of Autism Family
}

\author{
Yopi Kusmiati \\ Lecturer of Faculty of Science of Dakwah and Communication \\ Syarif Hidayatullah State Islamic University Jakarta, Indonesia \\ Email: yopi.kusmiati@uinjkt.ac.id
}

\begin{abstract}
Management of Impression is always done almost by everyone with a variety of reasons, when someone interact with others, in order to get a good impression, positive impressions, impressive impressions, and so forth. Usually, impression management is done to improve social status, in order to gain respect from others, to obtain a certain position, or for political needs and financial benefits. Impression management is not only done orally or writing, but also uses visual symbols (visible) such as action, appearance, or other objects. Impression management that someone does has certain purposes, to cover up events that can undermine his self-esteem. This can be done by autistic children family, to remain privileged in their environment, still regarded as an honorable family, and to remove the stigma from the environment. Impression management by the autism family is more about managing verbal impression, when telling the story of autistic children in their neighborhood to cover the stigma. The various feelings of shame, insecurity and want to cover them sometimes afflicted parents who have children with autism, because it is aware or not sometimes the behavior of "deviant" children with autism is not easily accepted by family and the environment. Families with normal children may allow their children to have conversation with their neighbors or peers without being accompanied or guarded. Families with autism children always try to display various tactics of impression management as far as they can afford, as they attempt to avoid or prevent the stigma inherent in people's judgment of their families as families with autistic children. Efforts to avoid stigma are generally not realized by families and communities. However, the existence of the stigma itself is clearly felt by the stigmatized person. Based on the results of the study, there are three categories of family impression management at home, i.e; informative impression, academic impression and the impression of "ignorant".
\end{abstract}

Keywords: impression management, autism, stigma

\section{INTRODUCTION}

Self-presentation is done by impression management in the presence of others, in getting a good impression from others, especially from new people. When a person has shortcomings and consider a disgrace by others, then the person will do the impression management to remain considered perfectly. So, families who have children with autism and who are considered stigma by the community. Families, who are considered to have a stigma will certainly play a role that they specifically create as a presentation of themselves. They will do impression management in various ways as they are not be considered a stigma, because not all family members can accept the stigma of the community.

The emergence of a variety of feelings such as shame, insecure and want to cover themselves will sometimes descend parents who has children with autism, because it is aware or not sometimes the behavior of "deviant" children with autism is not easily accepted by family and the environment. Families with normal children may allow their children to chat with their neighbors or peers without being kept or worried. In contrast, families with children's autistic, they have feeling "worry" that the child will interfere with peers and the people around him, and it led to makes the family always monitor and watch the child, so not infrequently parents and families present themselves by using certain tactics to cover the shortfall, as a result their children's deficiencies do not look "flashy" and attract the attention of the people around them.

Families with autistic children try to present selfpresentation tactics as far as they can, because they want to avoid or prevent the stigma attached to the assessment of as families with autistic children. Efforts to avoid stigma are generally not realized by families and society. But the existence of the stigma itself is clearly felt by the stigmatized person[1].

\section{METHODS}

The subjects of this study were parents who had autistic children in the Jakarta area who were selected purposively based on their criteria and willingness to explore their experiences consciously. There are six families of autistic children who were made informants in this study, consisting of twelve people, six autistic children's mothers, five autistic children's fathers, and one sister autistic child.

This research was conducted using constructive paradigm with dramaturgy approach from erving goffman. The use of dramaturgy in this study to look at the family's behavior of autistic children when interacting with their environment, as a result the researchers found tactics management of families impression who had autistic children and emerged through the symbols and meaning learned through interaction with people around them[2].

Impression management is not only done with speech or writing, but also uses visual symbols (visible) such as action, appearance, vehicle, house, or other objects. Impression management is a process of arranging arrangements, words, nonverbal communication, and the use of clothing to create an image of individuals and situations[3].

Furthermore, in this study the researcher will make informative typing which then made a model based on the actions of the informants that researchers encountered. This is in accordance with postulates put forward by 
schutz that a phenomenologist develops a model of human action, generally with 3 postulates or arguments according to Wilson, t.d. (nd)[4] follows:

a. The postulate of logical consistency, in which the validity of a scientist's construction is guaranteed and distinguished from the construction of everyday life;

b. The postulate of subjective interpretation, in which the scientist may refer '... Any kind of human action or subjective outcome such as the act or result of an actor's act;

c. The postulate of adequacy: that is the constructs created by the researcher must be understood by the individual social actor and his followers. Compliance with postulates ensures that scientific construction is consistent with the construction of a sensible experience of the social world.

\section{RESULT AND DISCUSSION}

The impression management was done by informants in home environment is unlike the impression management that most people do. In general, humans do the impression management with symbols such as clothing, shelter, or other accessories. The informants in this research performed the management of the impression through the verbal language they used either directly or indirectly, so it looked unique. Researcher found some criteria of impression management conducted by informants as follow: the informative impression, academic impression, and the impression "ignorant".

\section{A. Informative Impression}

An informative impression is the management of the impression performed by the autistic children of the family by initiating the conversation first. Before anyone else asked the child or his family, they had already told the other person the condition of his child, although others had not asked yet. There are six informants included in this category, namely BA, SBA, BN, SBN, MZ, and SMZ informants (names are using initials)

BA and SBA informants, they both never manages the impression of it in his home, workplace and school environment. Because they think, they are not ashamed to tell their son's condition to anyone, because they want others to know the true condition of $\mathrm{AD}$, so $\mathrm{AD}$ can be accepted in the environment. BA also does not hesitate to tell her friends, even if is not asked. When neighbors know the state of autism AD, BA does not feel the rejection of them, but instead gets their support. Her neighbors gave much information about autism, and sought therapy for autistic children, which made BA even stronger in the face.

From the BA expression, the researcher saw that she was managing an impression when telling about AD to her friends without being asked, which according to the researchers precisely that was BA way to avoid any "weird" assumption about AD, and other unwanted assumptions. So, the way of BA tells friendly, warmly, and positively about AD. Here the researcher sees that by telling the story of all the advantages of $\mathrm{AD}, \mathrm{BA}$ wants $\mathrm{AD}$ to be regarded as a person with an advantage, not a person who has only shortcomings, and does not want to be deemed flawed. Also, when the first time the BA family moved in a new environment. The same thing was done by SBA, by directly telling the real condition of the $\mathrm{AD}$, with same reason. Some of the neighbors that researcher met also said that they knew the condition of $\mathrm{AD}$ from SBA information, when they first lived in the neighborhood. This is based on the recognition of one of the neighbor with initials ST when researcher had the opportunity to talk with him.

Based on the SBA expression that tells its neighbors that $\mathrm{AD}$ is at a public school, it is an impression management of SBA, so that $\mathrm{AD}$ gets an impression as an autistic child who still has the ability to be non-autistic children, without the need to be admitted to special school (SLB). Public schools receive children with autism, which are called inclusive schools. Autistic child's peers are conditioned to help children with autism over some of its limitations. The strange behavior of an autistic child in an inclusive school is not particularly noticed by other students and teachers. Treatment with other students, making children with autism have pride to express their abilities. Special schools (SLB), is generally avoided by families of children with autism as a place of education of their children.

The impression management was also performed by SBA informants to the researcher when they first met. SBA informant revealed that if $\mathrm{AD}$ is a child who is independent and neat, has good academic ability. SBA stories are also usually convey to mothers in the neighborhood, so neighbors around have also already known the other AD strengths.

According to the security guard, the SBA family is a family that is quite familiar with them and with local people. They also know AD condition from BA and SBA, so all the security guards in complex are familiar with $\mathrm{AD}$, who often walks around the complex environment with SBA.

Not only BA, SBA often tells about AD to the fathers who are in their housing complex. Mostly, on weekend in the morning and afternoon, SBA informant goes with $\mathrm{AD}$ to walk down the street their complex. And usually SBA informant meets some of fathers who are doing sports or just chatting ordinary.

When someone asked about the AD, the SBA informant told of $\mathrm{AD}$ capabilities and the development of $\mathrm{AD}$, so that others were happy with the AD.

The informative impression was also done by the $\mathrm{BN}$ family. Although she said she always said the condition of TS without managing the impression made, but verbally, she has done the impression management. $\mathrm{BN}$ informant often tells the development of TS to the mothers around her residence. When the researcher asked why $\mathrm{BN}$ tells the truth about the actual condition of the $\mathrm{TS}$, according to $\mathrm{BN}$ it will further ease the burden and gain support from others.

From BN expression, the researcher assumes that $\mathrm{BN}$ does not want to be snickered or mocked by her neighbors, so she explains clearly about her son TS, in order to get empathy from them. This phenomenon becomes interesting, because the phenomenon in big cities tend to put forward individual behavior, not communal 
behavior. Viewed from the perspective of social change, this shows that urban characteristics, especially large cities, are not strictly attached to this group. One characteristic of urban life is that urban society generally more individual, social distance and lack of social tolerance among citizens. While the habit of gathering, and taking care of the neighbors, usually exists in people's lives that have a closer relationship pattern, such as in a villages. Therefore, the ongoing communication mechanism also continues to adopt the usual patterns in the township, so the impression management should be done, as it takes into account the views and opinions of others.

The same thing has been done by SBN informant, who were very concerned with the environment where he live. SBN also never hesitate of his son to people around them, and share their experiences with them, so there is no impression of covering the TS situation. The SBN informant also shared experiences with his new neighbor. He also shared TS activities at school and told TS shortcomings as well as the habits of TS that are different from other children. This is based on information from SBN neighboring that researcher encounter at his home with his expression as follows: "we know SBN have autism children from SBN himself. I have heard in the night there was the sound of cryied, then when I met MR. SBN I asked, what's wrong? MR. SBN said it was his son's voice. Autistic child act, “.

Thus, MZ and SMZ informants. When telling about they son $A Z, M Z$ also often highlight the strength of his son. $M Z$ tells about the AZ proficiency of swimming since the age of 3 years, AZ has ability in painting and cooking. According to the researchers, the story is an impression management conducted by MZ so that their autistic children not only seen the shortcomings.

Based on MZ's expression that she never felt embarrassed to tell AZ things to her neighbors and friends, even having a blog where she told all about AZ and AZ's daily developments was the way MZ manages the impression when she's really sincere AZ, although she is also unconcerned about neighbors talks and one of her sisters-in-law who is not particularly like of AZ's presence.

In the home environment, MZ and SMZ informants did not communicate very often with their neighbors, because of the environmental factors in which they lived in the apartment, but when they met their neighbors they also liked to tell AZ abilities in all fields. Not only that, while go shopping at the shops which are not far from where they live too, almost all employees there know exactly about AZ. They knew that AZ autism from MZ informants who has told about $A Z$, even they also like to help $\mathrm{MZ}$ to invite $\mathrm{AZ}$ to communicate, for example by asking AZ to leave or take the goods at the custodian, then asked AZ to say thank you. The relationship between AZ and employees in the mall also looked familiar. This is the management of the impression of $\mathrm{MZ}$ and SMZ informants. The next impression is the academic impression.

\section{B. Academic Impression}

The academic impression is the management of an impression made by the families of autistic children to get the impression that their family is an educated family, who is very understanding of autistic children. There are two informants included in this category, namely MJ, and SMJ.

At her home environment, MJ told that JG was very clever in tell stories through his writings on computer, and with a very good literary. MJ did not want to label her child with an autism label, or anything else. She just said that her son JG has a deficiency that must be fixed. For MJ, the strength of JG is something extraordinary, which is not necessarily owned by other children.

However, although there are neighbors who was thinking negatively of their families, MJ was also not concerned with that assumption, because she though people who think like that is people who do not understand what is autism. Though there are some of them who have concern for autism, although not from their families.

The impression MJ shows that her family is an educated family, who understands the health and development of the child. So she wants to eliminate the impression that she is a mother who can not take care of children. In fact she made the impression that people who judge negatively on JG is a person of low education and knowledge. This was always done when there were neighbors or friends who asked about $\mathrm{JG}$, or when there were neighbors who always see "cynical" to JG. Likewise with SMJ informant. When at home, he is not too afraid of his neighbors' assumption of their child. According to him, if anyone thinks strange to their child, it's because of their ignorance about autism. And he never think about that.

This method of impression management is humane to do. This is influenced by the existing motivation in the family. As Argyle [5] points out, there are three primary motivations for impression management: the desire to obtain material or social rewards, to maintain or enhance self-esteem, and to facilitate the development of selfidentity (creating and establishing self-identity). Academic impression can be identified with the management of an impression based on the motivation to maintain or improve self-esteem, and to establish identity as an educated person who is very familiar with autism. The next impression is the impression "ignorant".

\section{The Impression of Ignorant}

Impression of ignorant is indifferent in the impression that researcher saw from the family of children with autism who have no psychological burden of having children with autism. They ignore others' view of the "fate" that befell them. The meaning of life lies in the value of each human being. There are four informants included in this category, namely MR, MY, SMY and VM.

This could be seen in the way MR in managing the impression. MR was not too concerned with the assumption of neighbors or anyone. She would be better portrays herself as a responsible mother by bringing her 
child therapy to various places. According to the researcher, this is one way of MR to eliminate negative assumptions from people in her neighborhood, so MR was not too concerned with the "chatter" of people around him. Based on the story of MR, since the small hospital she was used to hearing the neighbors every day, either directly or indirectly heard by her, but she pretended not to hear the person's talk. This, according to researchers, MR wants to be considered a strong person, not dissolved in sadness and not feel eliminated by the environment. Especially when MR had a neighbor who always mocks the MR family with painful words, such as: "his mother is lazy", "i'm not ashamed to have a disabled child", but all that is not regarded by MR. She tried to be ignorant with all the assumptions of people, even MR assisted by her parents who took care of the RS to explain to the neighbors about the condition of the RS, so for MR explanation of his parents is enough, without having her explain. Nevertheless, MR never feel embarrassed to take the RS anywhere, come to family gathering, or meet with her friends.

The same has been done by the MY informant who managed the impression by presenting herself as a mother who always keep YS with patience, even without the help of her husband. He proved to her neighbors that YS was not a troublesome child, but just needs special attention from her. She also did not care about his neighbors' assumption. This might be due to the position of the house in a fairly large complex, where individualistic characteristics were more visible and rarely meet with other neighbors, except in an event, such as arisan (regular social gathering) or there is a celebration and pengajian (recitation) in a complex of mosque. Some neighbors know the condition of YS, especially the neighbors where YS was always playing, who has been told by MY informant. MY and SMY informants were also rarely bersilaturrahmi (stay in touch) with neighbors, as well as their children YS and VM. This makes the VM informant also "indifferent" to her environment, and does not care about people's assumption about her brother YS. When inviting YS to play outside the house, on the field, or in the complex, the VM informant is not embarrassed or uncomfortable. For her, she is happy to be able to invite YS to play with her, because the opportunity VM to play with YS is not often, depending on YS conditions.

MY informant also did not care about the neighbors who always think her child is handicapped, and some even think crazy. She still invites the person to chat, because she thinks the neighbor does not know, and his knowledge has not arrived there. According to MY, she initially felt ashamed to have children with autism, but over time she was immune to the shame, although often miscommunication between MY informants with her husband SMY.

The author found that there are some researchers who examined about children with autism, but they did not look to the management of the impression of autistic families, but with a different perspective with the author. They are Dyah Sekaringsih [6] entitled "The Role of Training (Mother Function in Applied Behavior Analysis of ABA) to self-efficacy of mother with child with autistic children." Sekaringsih research only provides training to mothers by doing pretest and posttest, regardless of the condition of children with autism, while research that the authors do, making families with autism as the subject of research.

In addition, the study of Abdul Hadi et al [7] in collaboration with the ministry of women empowerment and child protection with the title "Portrait of Children With Special Needs (Children With Special Needs) in Palembang". Hadi et al research is a research report that the results of his research found that there are various definitions given to autism. His research was not focused on children with autism alone, but also to all children with special needs, by looking at the views of the public and the government against the children with special needs.

Further research was conducted by Adriana Soekandar Ginanjar [8] for his dissertation in the field of psychology entitled "Understanding the Spectrum of Autistic Holistic". This Ginanjar research is so broad, so it does not focus on one individual problem of autism. His research includes the description of the sensory aspects of the individual SA, its relation to perceptions of the outside world, the description of the psychological aspects of the individual SA, the autistic strengths and weaknesses in the cognitive, emotional and autistic social interaction, the image of religious and spirituality in the individual SA, and the factors that play an important role in the success of the individual SA. The research that the authors do more focus on the self-presentation of the family of children with autism.

\section{REFERENCES}

[1] G. Erving and Stigma, Notes on the Management of Spoiled Identity. New York: Touchstone, 1986.

[2] E. Kuswarno, Fenomenologi (Konsepsi, Pedoman, dan Contoh Penelitiannya). Bandung: Widya Padjadjaran, 2009.

[3] W. Julia T, Communication Theories in Action (An Introduction). Belmont, USA: Wadsworth, 2004.

[4] W. T.D, "Alfred Schutz, phenomenology and research methodology for information behaviour research."

[5] M. Argyle, The Psychology of Interpersonal Behaviour. USA: Penguin Books Limited, 1994.

[6] D. Sekaringsih, "Peran Pelatihan 'Fungsi Ibu dalam Latihan Metode ABA (Applied Behavior Analysis' terhadap self-Efficacy Ibu dengan Anak Penyandang Autisme. Tesis.," Universitas Padjadjaran, Bandung, 2008.

[7] A. Hadi and Abdul, "Potret Children With Special Needs (Anak Berkebutuhan Khusus) di Kota Palembang" PSG IAIN RF, Palembang, 2009.

[8] A. S. Ginanjar, 'Memahami Spektrum Autistik Secara Holistik', Universitas Indonesia, Jakarta,. 